\title{
PENGARUH BHAGAWAD GITA BERGAMBAR DAN VISUAL LITERACY TERHADAP PEMAHAMAN AJARAN HINDU SISWA SMP DI PASRAMAN TIRTA BHUANA BEKASI
}

\author{
Oleh :
}

I Ketut Ulianta (E-mail : ulianta@ stahdnj.ac.id)

I Ketut Angga Irawan (E-mail : ketutanggairawan@stahdnj.ac.id)

I Putu Sudarma Putra

I Kadek Nova Wibawa Yasa

\begin{abstract}
The purpose of this study to identify whether the use of different learning instructional media, that is Bhagawadgita in the form of picture book and Bhagawadgita in the form of plain text book, for students with different level of visual literacy, will results in any differences in the students' understanding of the Hinduism value. This study aims to find out the answer to the questions (1) whether there are differences in the understanding of Hinduism value of students who in the learning process use Bhagawadgita in the form of picture book compared to those who use Bhagawadgita plain text book; (2) whether there are differences in the understanding of Hinduism value of students with a high visual literacy level who in the learning process use Bhagawadgita in the form of picture book compared to those who use Bhagawadgita plain text book; and (3) whether there are differences in the understanding of Hinduism value of students with a low visual literacy level who in the learning process use Bhagawadgita in the form of picture book compared to those who use Bhagawadgita plain text boo.

This study applies Quantitative Analysis with Quasi-Experimental Design. The population are IX grade students of Pasraman Tirta Bhuana Bekasi of Academic Year 2016-2017. Samples are taken from the population using random sampling technique with a drawing method. The sample size are 32 students devided into two groups. Different treatment on the learning instructional media is given to each group after visual literacy of all samples are measured.

Validity and reliability of the instrument are tested using Product Moment Correlation Technique and Alpha Cronbach's respectively. Two Way Analysis of Variance (ANOVA) with Treatment by Level Design is applied for data analysis.

The results of this study are (1) there are differences in the understanding of Hinduism value of students who in the learning process use Bhagawadgita in the form of picture book compared to those who use Bhagawadgita plain text book; (2) the average learning outcome of students who have a high visual literacy level and use Bhagawadgita in the form of picture book is higher than those who use Bhagawadgita plain text book; and (3) the average learning outcome of students who have a low visual literacy level and use Bhagawadgita in the form of picture book is higher than those who use Bhagawadgita plain text book.
\end{abstract}

Keywords : Bhagawad Gita in the form of picture book, Visual Literacy, Learning Outcome. 


\section{PENDAHULUAN}

Hasil studi pendahuluan yang dilakukan oleh peneliti, tampak bahwa minat belajar siswa di pasraman kurang. Siswa menganggap bahwa pasraman hanya untuk mengejar nilai Agama, bukan sebagai sebuah kebutuhan. Hal ini dibuktikan dengan rendahnya tingkat kehadiran siswa setiap minggunya (60-70\%), sementara pada saat UTS atau UAS tingkat kehadiran mencapai $100 \%$.

Bhagawad Gita terjemahan bergambar adalah salah satu upaya implementasi teknologi pendidikan berwujud pengembangan media pendidikan agama Hindu dalam bentuk sloka yang dilengkapi gambar-gambar yang diharapkan mampu memberikan pengalaman belajar yang lebih kongkrit dari pada hanya dideskripsikan dalam lambang-lambang verbal berupa kalimat-kalimat dan kata-kata.

Edgar Dale dalam kerucut pengalaman yang ditemukan menggambarkan bahwa pengalaman melalui gambar-gambar menempati urutan ketiga lebih kongkrit dari pada lambang visual dan lambang verbal. Meskipun demikian dalam pemahaman materi pembelajaran dalam bentuk gambar-gambar membutuhkan kemampuan memahami dan menggunakan gambar termasuk pula kemampuan untuk berpikir, belajar, serta mengekspresikan gambar tersebut yang didefinisikan sebagai Visual Literacy. Penggunaan Bhagawad Gita bergambar diharapkan akan lebih menarik perhatian dan minat belajar siswa yang pada akhirnya akan meningkatkan pemahaman agama. Untuk mengetahui efektivitas Bhagawad Gita terjemahan dalam gambar dalam memberikan kemudahan dalam pemahaman tentang pengetahuan agama Hindu kepada siswa peneliti memandang perlu untuk mengangkat penelitian dengan judul "Pengaruh Penggunaan Bhagawad Gita Versi Terjemahan Bergambar terhadap Pemahaman Ajaran Hindu pada Aspek Yajñya dengan Mempertimbangkan Visual Literacy pada Siswa SMP di Pasraman Tirta Bhuana Bekasi”

Pemilihan salah satu materi penting yaitu tentang Yadnya dalam mata pelajaran agama Hindu yang diajarkan di Pasraman adalah semata-mata agar saat penelitian dilakukan, tidak mengganggu pembelajaran yang telah direncanakan oleh Lembaga.

Secara etimologi pengertian Yadnya adalah korban suci secara tulus ikhlas dalam rangka memuja Hyang Widhi. Pada dasarnya Yadnya adalah penyangga dunia dan alam semesta, karena alam dan manusia diciptakan oleh Hyang Widhi melalui 
Yadnya. Yadnya bukanlah sekedar upacara keagamaan, lebih dari itu segala aktivitas manusia dalam rangka sujud bhakti kepada hyang Widhi.

Dalam Bhagawad Gita terdapat sloka - sloka yang menerangkan pentingnya pelaksanaan yadnya sebagai wujud sujud bhakti kepada Hyang Widhi Wasa.

Berbagai permasalahan yang dapat diidentifikasi antara lain belum optimalnya upaya prioritas yang dilakukan dalam mengatasi verbalisme dalam pendidikan, relevansi antara tujuan pembelajaran, materi, metode, media dan evaluasi yang diterapkan dalam proses pembelajaran, efektivitas Bhagawad Gita sebagai media pendidikan hindu masih bersifat abstrak sehingga perlu upaya-upaya membuat lebih kongkrit sehingga memudahkan siswa untuk memahami isinya.

Peneliti merasa perlu untuk mencari upaya meningkatkan kemampuan Visual Literacy siswa Hindu untuk lebih memahami lambang visual, dengan meneliti pengaruh penyajian Bhagawad Gita terjemahan bergambar dan Visual Literacy siswa SMP terhadap pemahaman ajaran agama Hindu.

Untuk lebih efektif dan efisien serta menjamin terfokusnya permasalahan maka penelitian ini dibatasi dalam aspek media pendidikan dan Visual Literacy yaitu mengenai pengaruh penggunaan Bhagawad Gita terjemahan bergambar terhadap pemahaman ajaran agama Hindu dengan mempertimbangkan Visual Literacy pada siswa SMP dengan rumusan masalah sebagai berikut:

1 Apakah terdapat perbedaan pemahaman ajaran Hindu antara siswa yang diberikan media pembelajaran Bhagawad Gita terjemahan bergambar dengan yang diberikan media Bhagawad Gita dalam bentuk teks?

2 Apakah terdapat perbedaan pemahaman ajaran Hindu antara yang diberikan media pembelajaran Bhagawad Gita Terjemahan dalam gambar dengan yang melalui pembelajaran dengan media Bhagawad Gita dalam bentuk teks bagi siswa yang memiliki Visual Literacy tinggi ?

3 Apakah terdapat perbedaan pemahaman ajaran Hindu antara yang diberikan media pembelajaran Bhagawad Gita Terjemahan dalam gambar dengan yang melalui pembelajaran dengan media Bhagawad Gita dalam bentuk teks bagi siswa yang memiliki Visual Literacy rendah?

Manfaat penelitian dibagi dua yaitu manfaat Teoritis dan Praktis. Manfaat Teoritis yaitu 1) Sebagai sumbangan bagi kajian Pendidikan Hindu dan teknologi 
pendidikan dalam mengelola, memilih dan memanfaatkan media pembelajaran secara efektif. 2)Untuk pengembangan penelitian dalam pendidikan Hindu serta menambah khasanah keilmuan dalam kawasan teknologi pendidikan, sehingga melahirkan temuan-temuan baru yang memungkinkan pemanfaatan media untuk lebih mengkongkritkan materi pelajaran yang abstrak sehingga terjadi kemudahan belajar bagi peserta didik. Manfaat Praktis yaitu 1) Dapat digunakan oleh guru/dosen dalam mempertimbangkan pemilihan media yang tepat dalam mempermudah terjadinya pemahaman peserta didik sehingga verbalisme dapat dikurangi dan meningkatkan motivasi belajar dan pembelajaran menjadi menyenangkan. 2) Dapat memotivasi siswa agar terlaksananya pembelajaran mandiri dan terbuka sehingga tumbuh kreatifitas dan kemandirian.

\section{PEMAHAMAN AJARAN HINDU DALAM BHAGAWAD GITA}

Pemahaman adalah tingkatan belajar yang tergolong domain kognitif tingkat kedua setelah pengetahuan mengingat. Pemahaman menunjukkan kemampuan memahami materi pembelajaran. Dari pemahaman ini akan mampu menjelaskan atau membedakan sesuatu.

Kemampuan pemahaman ini menyangkut :

a. Penerjemahan (interpreting), yaitu verbalisasi atau sebaliknya

b. Memberikan contoh (exemplifying), yaitu menemukan contoh-contoh yang spesifik.

c. Mengklasifikasikan (classifying), yaitu membedakan sesuatu berdasarkan kategorinya.

d. Meringkas (summarizing), yaitu membuat ringkasan secara umum

e. Berpendapat (inferring), yaitu memberikan gambaran tentang kesimpulan yang logis.

f. Membandingkan (comparing), yaitu mendeteksi hubungan antara 2 ide atau obyek.

g. Menjelaskan (explaining), yaitu mengkontruksi model sebab akibat (Munir, 2008, p. 55).

Bhagawad Gita, adalah Nyanyian Brahman dalam bentuk sloka yang indah yang merupakan dialog antara Kresna dan Arjuna yang terjadi sebelum perang saudara yang berkecamuk hebat (Mahabharata) antara seratus putera Dhrtarastra dengan saudara-saudara misannya para Pandawa atau para putera Pandu. Bhagawad Gita disabdakan oleh Sri Krisna kurang lebih pada 50 abad yang silam yaitu pada awal zaman Kali.(Prabhupada, A.C Swami Bhaktivedanta, 2006, p. xix). 
Triguna, merekontruksi Kitab Bhagawad Gita terdiri dari 700 untaian sloka, 18 Bab sebagai satu kesatuan yang utuh. Bagian Pertama (bab I-VI) melukiskan dialog tentang hakikat disiplin kerja tanpa mengharapkan hasil kerja itu sendiri dan hakekat eksistensi sifat jiwa yang melekat pada tubuh manusia. Bagian Kedua (bab VII - XII) berisi dialog tentang hakikat ilmu pengetahuan dan hakikat Brahman sebagai Tuhan Yang Maha Esa dan Bagian Ketiga (bab XIII-XVIII) berisi dialog yang menyimpulkan bagian pertama dan kedua yang pada hakikatnya menguraikan doktrin disiplin seluruh jiwa dan raga sebagai landasan kerja yang diabadikan sebagai persembahan kepada Brahman (Tuhan Yang Maha Esa)(Gun, 2011, p. viii).

Hakekat segala pengetahuan Weda dan salah satu diantara Upanisad-upanisad yang paling penting dalam kesusastraan Veda karenanya disebut juga Gitopanisad. Maksud dari Bhagawad Gita ialah untuk menyelamatkan manusia dari kebodohan kehidupan material dan menjelaskan lima kenyataan pokok yaitu : ilmu pengetahuan tentang Tuhan (Isvara), kedudukan pokok makhluk hidup atau para jiva, Prakrti (alam material), kala atau waktu dan Karma (kegiatan). Jadi lebih jelasnya dari Bhagawad Gita kita dapat mempelajari apa arti Tuhan Yang Maha Esa, para makhluk hidup, prakrti manifestasi dari alam semesta, bagaimana alam semesta dikendalikan oleh waktu dan bagaimana kegiatan makhluk hidup.

\section{MEDIA PEMBELAJARAN}

Proses belajar mengajar merupakan komunikasi antara sumber pesan dengan penerima pesan. Dalam hal ini guru sebagai pengirim pesan atau sumber pesan, dan peserta didik adalah sebagai penerima pesan yang disampaikan. Disamping itu juga melibatkan perantara atau media. Media merupakan komponen yang sangat penting dalam proses tersebut. Secara etimologis, media berasal dari bahasa latin merupakan bentuk jamak dari "medium" yang berarti tengah, perantara atau pengantar. Istilah perantara atau pengantar ini digunakan karena fungsi media sebagai perantara atau pengantar pesan dari si pengirim kepada penerima pesan(Asyhar, 2011, p. 4).

Terdapat dua cara untuk memperoleh pengalaman belajar yaitu secara langsung dan tdak langsung. Pengalaman langsung diperoleh dengan melakukan sesuatu kegiatan dimana peserta didik melakukan sendiri aktivitas yang dipelajari secara mandiri ataupun dibawah bimbingan guru. Sedangkan pengalaman tidak langsung 
diperoleh dengan menggunakan alat baik software maupun hardware baik itu film, foto, gambar dan lainnya yang disebut media.

Penggunaan media yang tepat, berimplikasi pada (1) adanya interaksi langsung dengan media pembelajaran ini memberikan peluang peserta didik berinteraksi dengan lingkungannya: (2) media pembelajaran menghasilkan kesamaan persepsi antar pengirim dan menerima pesan-pesan pembelajaran; (3) media pembelajaran dapat memberikan konsep dasar yang benar, kongkrit, dan realistis; (4) media pembelajaran dapat meningkatkan keinginan dan minat baru; (5) Media meningkatkan motivasi dan merangsang peserta didik untuk belajar; (6) media dapat memberikan pengalaman yang menyeluruh baik yang kongkrit maupun yang abstrak.

\section{VISUAL LITERACY}

Dalam mengkomunikasikan ide atau gagasan-gagasan kita dapat menggunakan teknik-teknik komunikasi yang bisa dikelompokkan ke dalam dua jenis. Yang pertama adalah teknik verbal seperti yang banyak dilakukan oleh sebagian besar orang menggunakan lambang-lambang verbal berupa kata-kata baik secara lisan maupun tertulis, yang kedua ialah teknik visual dengan menggunakan gambar, foto maupun lambang-lambang visual.

Komunikasi visual mempunyai keuntungan sendiri dalam hal ini, ketika suatu objek yang jauh letaknya dari tempat kita berada dan tidak mungkin dijangkau secara langsung, dapat "diindera" melalui visualisasi obyek tersebut, misalnya direkam atau digambarkan atau dalam bentuk film maupun video. Seperti peristiwa meletusnya gunung merapi di tempat yang jauh. Dengan demikian, biayapun sangat murah dan mudah dibandingkan dengan melihat secara langsung. Bentuk komunikasi visual dapat menarik dibandingkan dengan hanya cara verbal. Dengan demikian sasaran lebih dapat berkonsentrasi kepada obyek yang disajikan.

Agar proses komunikasi dalam bentuk visual tersampaikan secara tepat dan benar, maka seseorang memerlukan kemampuan dalam memahami dan menggunakan gambar termasuk pula kemampuan untuk berfikir, belajar, serta mengekspresikan gambar tersebut. Kemampuan ini disebut sebagai Visual Literacy.

Menurut Robert Heinich et al, Visual Literacy adalah kemampuan yang dapat dipelajari untuk menterjemahkan pesan-pesan visual secara tepat dan menciptakan 
pesan-pesan visual. Apabila didefinisikan dalam pembelajaran, maka Visual Literacy adalah kemampuan peserta didik untuk menganalisis sebuah pesan visual dalam pembelajaran. Ia mengatakan dalam bukunya yang berjudul Instructional Media sebagai berikut : Visual Literacy is the learned ability to interpret visual messages accurately and to create such messages.(Heinich, Robert, Michel Molenda, 1982, p. 62). Visual Literacy dapat dikembangkan melalui dua macam pendekatan yaitu melalui Strategi pertama : Input strategis dengan membantu peserta didik untuk decode atau "membaca" dengan cara mempraktekkan kemampuan analisis visual. Input strategis adalah membantu perserta didik untuk membaca, membaca sandi, kecakapan visual melalui praktek atau latihan menganalisis visual. Contoh: analisis gambar, diskusi multimedia, dan program video. Strategi kedua : Output strategis yaitu dengan membantu peserta didik untuk encode, atau "menulis" secara visual. Output strategis adalah membantu peserta didik menulis dalam menyandikan, menulis visual untuk mengekspresikan diri mereka sendiri dan berkomunikasi dengan yang lain. Misalnya merencanakan dan memproduksi presentasi visual. Membaca sandi atau mengartikan visual. Pengkodean atau penyandian yaitu kemampuan di dalam menerjemahkan dan menciptakan makna dari rangsangan yang ada di sekelilingnya. Mengkodekan (menciptakan visual) Kemampuan visual melalui kreasi pelajar dalam menyajikan visual. Seperti memproduksi visual dapat meningkatkan pandangan efektif atas pemahaman visual.

\section{KERANGKA TEORITIK}

1. Perbedaan pemahaman ajaran Hindu antara siswa yang diberikan media pembelajaran Bhagawad Gita terjemahan bergambar dengan yang melalui pembelajaran dengan Bhagawad Gita dalam bentuk teks. Disajikan dalam skema berikut :

\section{SKEMA KERANGKA TEORITIK 1}

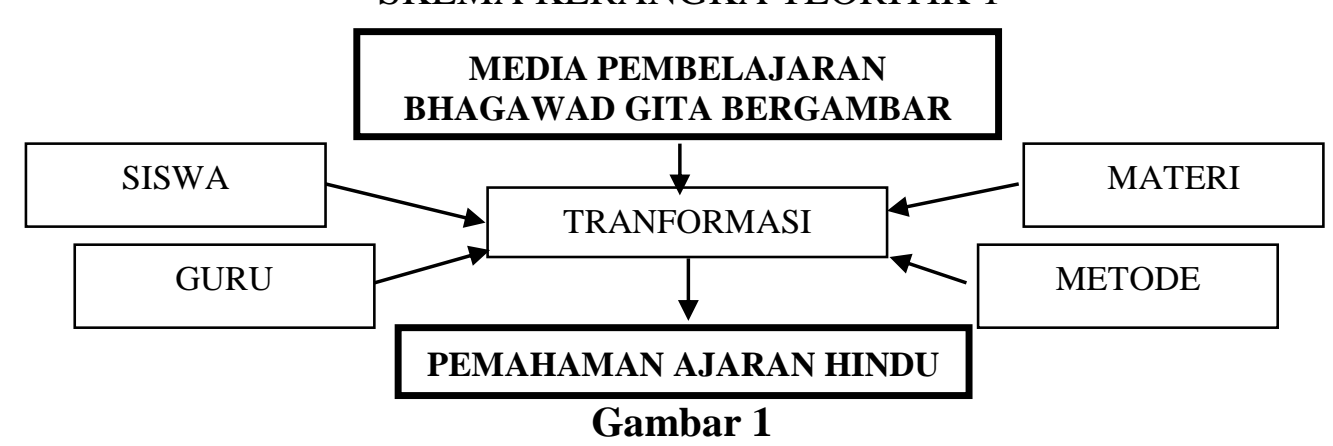


Banyak faktor yang berpengaruh terhadap proses tranformasi pembelajaran dalam pencapaian hasil belajar yang optimal dalam hal ini pemahaman terhadap ajaran Hindu yaitu ajaran Bhagawad Gita. Media Pembelajaran adalah salah satu faktor yang merupakan faktor eksternal, yang memiliki fungsi dan sangat menunjang pembelajaran. Penelitian ini menggunakan pembelajaran dengan media visual (gambar) dan media buku teks.

Pertama, Pemanfaatan media pembelajaran visual dimaksudkan untuk memberikan pengalaman belajar yang lebih kongkrit kepada kepada siswa untuk belajar sehingga lebih memudahkan dalam pemahaman materi yang dipelajari sesuai dengan kebutuhannya sehingga menjadi lebih bermakna bagi dirinya. Dengan media visual berupa gambar diharapkan terjadinya perubahan pembelajaran yang lebih mandiri dan terjadi kegiatan mental yang lebih aktif, inovatif, kreatif dan menyenangkan sehingga motivasi belajar menjadi lebih tinggi.

Dalam pemanfaatan gambar visual sebagai media pembelajaran peran guru lebih diarahkan menjadi fasilitator dan membantu peserta didikan mana kala ada pertanyaan hal-hal yang belum dipahami. Jika efektifitas kegiatan pembelajaran dengan media gambar visual mampu diciptakan guru dengan berbagai kontrol langsung maupun tidak langsung terhadap kegiatan sehingga benar fokus pada pembelajaran sehingga pemahaman ajaran Hindu dalam Bhagawad Gita sebagai hasil belajar siswa yang diharapkan dapat tercapai secara optimal.

Kedua yaitu pembelajaran dengan media buku teks biasa yang nota bena lebih abstrak dari pada media gambar visual efektivitasnya tergantung sejauh mana minat, konsentrasi, perhatian serta kemandirian \& tanggung jawab terhadap diri sendiri dari siswa dalam membaca dan memahami lambang-lambang verbal dari kata dan kalimat di dalam buku tersebut yang dalam hal ini adalah buku Bhagawad Gita dalam penyajian teks biasa. Minat, konsentrasi dan perhatian siswa dapat di tingkatkan dengan membantu peserta didik dalam hal memperjelas terjemahan dengan penjelasan lebih detail dalam uraian bentuk lain dengan substansi makna yang sama dari para pendidik. Pemanfaatan buku teks akan efektif dengan didamping oleh pendidik dengan penjelasan tambahan dengan menyampaikan dan memperjelas pesan pembelajaran, menggunakan bahasa yang mudah dicerna siswa, menyajikan secara 
sistematis serta merangsang siswa untuk memberikan tanggapan melalui latihanlatihan sehingga terjadi komunikasi dua arah.

Jika guru mampu menjadi fasilitator yang baik, memotivasi agar siswa mau belajar mandiri secara seksama dan memiliki konsentrasi terhadap materi yang disajikan pembelajaran dengan buku teks dapat berhasil dengan baik.

Perlakuan dalam penelitian ini diberikan berbeda terhadap dua kelompok siswa yang terdiri dari kelas eksperimen mengikuti pembelajaran dengan media gambar visual dalam hal ini menggunakan media Bhagawad Gita terjemahan dalam gambar dan kelas kontrol yang mengikuti pembelajaran dengan media buku teks terjemahan Bhagawad Gita . Setelah diberikan perlakuan akan dilihat pengaruh media gambar visual terhadap pemahaman ajaran agama Hindu dalam Bhagawad Gita. Karena terdapat perbedaan antara kedua pembelajaran tersebut diduga pemahaman ajaran hindu siswa yang mengikuti pembelajaran dengan media gambar visual lebih tinggi dari pada yang mengikuti pembelajaran dengan buku teks.

2. Perbedaan pemahaman ajaran Hindu antara yang diberikan media pembelajaran Bhagawad Gita terjemahan dalam gambar dengan yang melalui pembelajaran dengan media Bhagawad Gita dalam bentuk teks, bagi siswa yang memiliki visual literacy tinggi, disajikan dalam skema berikut :

SKEMA KERANGKA TEORITIK 2

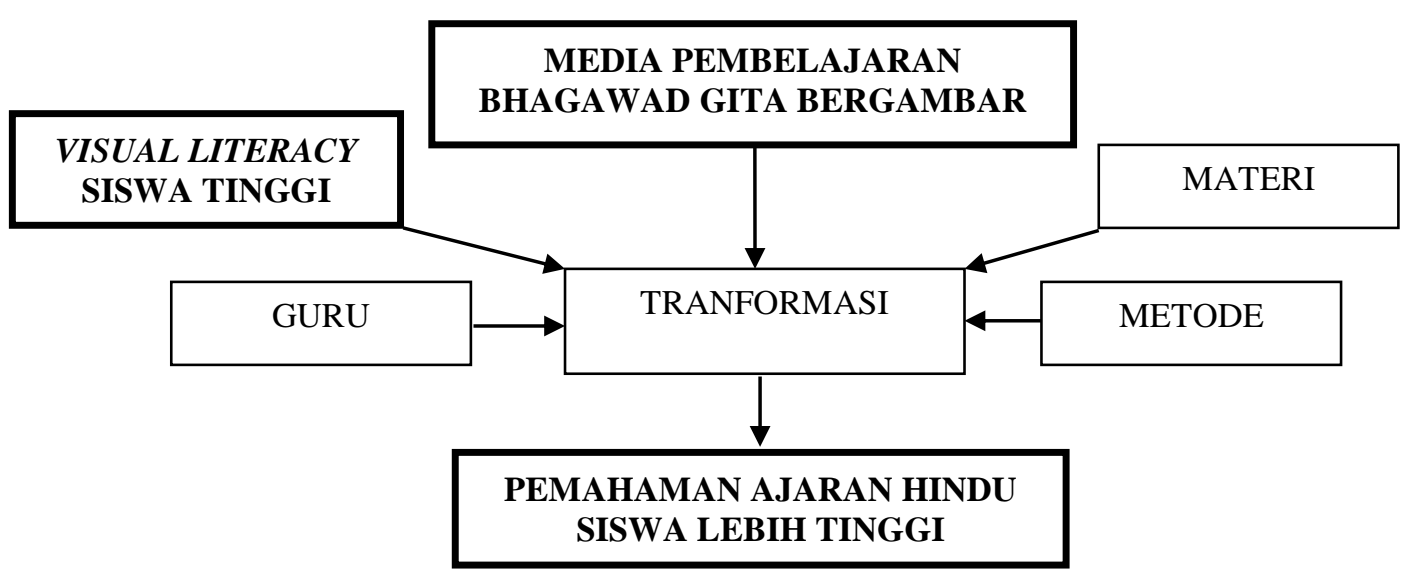

Gambar 2

Pemahaman ajaran agama Hindu dalam Bhagawad Gita yang berupa konsepkonsep yang mengadung nilai-nilai spiritual yang luhur, budi pekerti yang berupa dialog antara kresna dan arjuna penuh dengan ajaran rahasia dan abstrak membutuhkan media yang mampu mengkongkritkannya, didalam diri siswa 
dibutuhkan pula kemampuan penguasaan dan pemahaman konsep tersebut sehingga mampu membuat hubungan dan keterkaitan antar konsep ajaran. Dibutuhkan kemampuan Visual Literacy yang tinggi sehingga dapat dengan mudah menginterpretasi dapat mengapresiasi, belajar dan menterjemahkan setiap gambar yang ditampilkan dengan benar sehingga terdapat diperoleh kesamaan persepsi terhadap konsep-konsep yang dimaksud agar tidak terjadi kesalahan dalam menginternalisasi nilai.

Siswa dengan Visual Literacy yang tinggi dengan senang secara mandiri untuk menggali informasi dan mampu memahami dengan tepat maksud dan nilai-nilai yang terkandung dalam Bhagawadgita dengan terjemahan bergambar sehingga pembelajaran akan terjadi secara efektif. Berbeda dengan siswa dengan Visual Literacy yang rendah, pemanfaatan media visual berupa gambar diduga mengalami kesulitan dalam memahami dan memahami konsep nilai yang dimaksud dengan demikian diduga pemahaman ajaran Hindu siswa yang memiliki Visual Literacy tinggi dan mengikuti pembelajaran dengan media visual berupa gambar lebih tinggi dari pada yang mengikuti pembelajaran dengan media buku teks.

3. Perbedaan pemahaman ajaran Hindu antara yang diberikan media pembelajaran Bhagawad Gita terjemahan dalam gambar dengan yang melalui pembelajaran dengan media Bhagawad Gita dalam bentuk teks, bagi siswa yang memiliki visual literacy rendah disajikan dalam skema berikut ini :

SKEMA KERANGKA TEORITIK 3

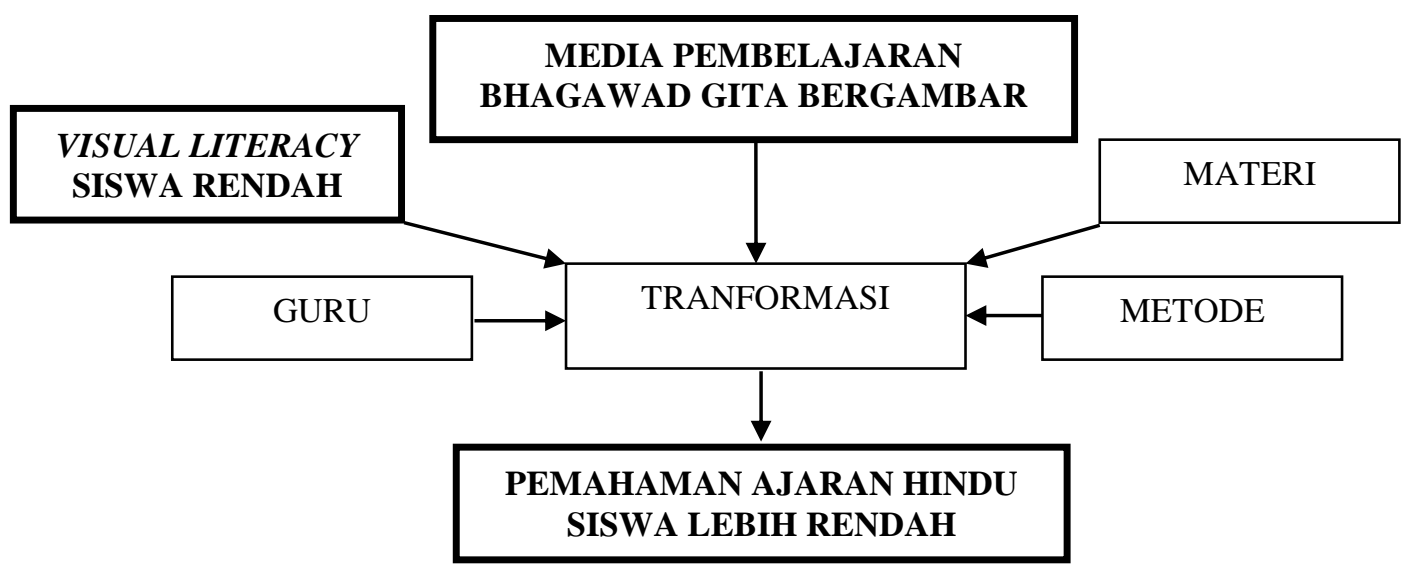

Gambar 3 
Siswa dengan Visual Literacy yang rendah, memiliki banyak kekurangan dalam hal pemahaman gambar-gambar visual terutama dalam memproduksi lambanglambang visual serta menterjemahkan/mengiterpretasi maksudnya. Perlu pengarahan dari guru/dosen dalam upaya pemahaman konsep-konsep yang abstrak sehingga menjadi lebih kongkrit dan lebih bermakna jika terdapat penjelasan lebih banyak secara tertulis sehingga pembelajaran dengan buku teks yang diarahkan dan dikontrol guru jika ada kesulitan akan lebih efektif untuk mendorong siswa dalam belajar. Guru juga harus lebih banyak memberikan motivasi kepada siswa untuk lebih berkonsentrasi dan menarik perhatian dengan berbagai contoh-contoh dalam kehidupan yang menarik dan sengaja dipersiapkan jika konsep dirasakan masih terlalu abstrak. Jika siswa diberikan media visual gambar dalam hal ini Bhagawad Gita terjemahan bergambar dalam pembelajaran diduga akan terjadi pembelajaran yang tidak efektif sehingga mempengaruhi hasil belajar dimana pemahaman siswa terhadap ajaran Hindu yang terkandung didalamnya menjadi rendah. Dengan demikian diduga pemahaman siswa yang memiliki Visual Literacy rendah dengan mengikuti pembelajaran dengan media visual berupa gambar lebih rendah dari pada yang mengikuti pembelajaran dengan media buku teks.

Berdasarkan kerangka teoritik diatas dirumuskan hipotesis sebagai berikut :

1 Terdapat perbedaan pemahaman ajaran Hindu antara siswa yang diberikan media pembelajaran Bhagawad Gita terjemahan bergambar yaitu lebih tinggi dari pada yang diberikan media Bhagawad Gita dalam bentuk teks.

2 Terdapat perbedaan pemahaman ajaran Hindu antara yang diberikan media pembelajaran Bhagawad Gita Terjemahan dalam gambar yaitu lebih tinggi dari pada yang diberikan pembelajaran dengan media Bhagawad Gita dalam bentuk teks bagi siswa yang memiliki Visual Literacy tinggi.

3 Terdapat perbedaan pemahaman ajaran Hindu antara yang diberikan media pembelajaran Bhagawad Gita Terjemahan dalam gambar yaitu lebih rendah dari pada yang diberikan pembelajaran dengan media Bhagawad Gita dalam bentuk teks bagi siswa yang memiliki Visual Literacy rendah . 


\section{METODE PENELITIAN}

Jenis penelitian ini adalah penelitian kuantitatif dengan menggunakan metode eksperimen dengan rancangan treatment by level 2 × 2 yang membandingkan dua pembelajaran yaitu penggunaan media visual (gambar dan buku teks dengan mempertimbangkan skor Visual Literacy siswa yang dibedakan atas skor Visual Literacy tinggi dan rendah, pengaruhnya terhadap pemahaman ajaran Hindu siswa.

Populasi adalah wilayah generalisasi yang terdiri dari objek atau subyek yang menjadi kuantitas dan karakteristik tertentu yang ditetapkan oleh peneliti untuk dipelajari dan kemudian ditarik kesimpulannya.(Sugiyono, 2008, p. 117).

Riduan(Riduan, 2011, p. 8), mengungkapkan populasi merupakan obyek atau subyek yang berada pada suatu wilayah dan memenuhi syarat-syarat tertentu yang berkaitan dengan masalah yang diteliti. Populasi target dalam penelitian ini adalah siswa SMP Pasraman Tirta Bhuana, populasi terjangkau adalah siswa kelas 9.

Teknik pengambilan sampel yang digunakan yaitu teknik random Sampling. Dalam 1 kelas, siswa dibagi menjadi 2 kelompok yaitu kelompok eksperimen dan kelompok kontrol. Sebelum diberi perlakuan siswa yang berada dalam masing-masing kelas ini diberikan kuesioner untuk mendapatkan data skor Visual Literacy mereka. Hasilnya kemudian diurutkan masing-masing dari skor tertinggi sampai terendah. Kemudian tiap kelompok dibagi menjadi 3 subkelompok yaitu kelompok skor Visual Literacy tinggi (35\%), kelompok skor Visual Literacy rendah (35\%) dan kelompok skor Visual Literacy tengah (30\%) tidak diikutkan sebagai sampel namun tetap diperlakukan sebagai mana siswa yang menjadi sampel di kelasnya. Kelas A1 sebagai kelompok eksperimen dan kelas A2 sebagai kelompok kontrol yang dipilih secara acak/random dengan cara diundi.

Analisa Data menggunakan software SPSS Ver. 23

Rancangan Penelitian

Rancangan sampel dalam peneltian ini dibagi dua kelompok. Kelompok pertama terdiri dari siswa yang mengikuti pembelajaran dengan penggunaan media belajar visual (gambar) yaitu Bhagawadgita bergambar, kelompok kedua terdiri dari siswa yang mengikuti pembelajaran dengan media Bhagawad Gita dalam bentuk buku teks biasa. Masing-masing kelompok perlakuan dibagi atas dua kategori yaitu siswa yang memiliki skor Visual Literacy tinggi dan kategori siswa yang memiliki skor 
Visual Literacy rendah. Data dalam penelitian ini meliputi data hasil belajar pemahaman ajaran Hindu Aspek Yadnya yang diambil menggunakan instrumen tes hasil belajar dan data Visual Literacy siswa yang diambil menggunakan instrumen non tes dalam bentuk rating scale dengan skala 5 .

Disain Penelitian dengan rancangan Treatment by level 2 x 2 dapat di gambarkan sebagai berikut :

TABEL 1

RANCANGAN \& DISAIN PENELITIAN

\begin{tabular}{|c|c|c|}
\hline $\begin{array}{c}\text { Media } \\
\text { Pembelajaran } \\
(\mathrm{A})\end{array}$ \\
$\begin{array}{c}\text { Visual Literacy (B) } \\
\text { Visual Literacy Tinggi } \\
\left(\mathrm{B}_{1}\right)\end{array}$ & $\begin{array}{c}\text { Bhagawad Gita } \\
\text { Visumbar) } \\
\left(\mathrm{A}_{1}\right)\end{array}$ & $\begin{array}{c}\text { Bhagawad Gita } \\
\text { Buku teks } \\
\left(\mathrm{A}_{2}\right)\end{array}$ \\
\hline $\begin{array}{c}\text { Visual Literacy Rendah } \\
\left(\mathrm{B}_{2}\right)\end{array}$ & $\mathrm{A}_{1} \mathrm{~B}_{1}$ & $\mathrm{~A}_{2} \mathrm{~B}_{1}$ \\
\hline & $\mathrm{A}_{1} \mathrm{~B}_{2}$ & $\mathrm{~A}_{2} \mathrm{~B}_{2}$ \\
\hline
\end{tabular}

Keterangan :

$\mathrm{A}_{1} \mathrm{~B}_{1}=$ Kelompok siswa yang memiliki Visual Literacy tinggi yang diberi perlakuan pembelajaran dengan media Bhagawad Gita bergambar.

$\mathrm{A}_{1} \mathrm{~B}_{2}=$ Kelompok siswa yang memiliki Visual Literacy rendah yang diberi pembelajaran dengan dengan media Bhagawad Gita bergambar.

$\mathrm{A}_{2} \mathrm{~B}_{1}=$ Kelompok siswa yang memiliki Visual Literacy tinggi yang diberi perlakuan pembelajaran dengan Bhagawad Gita dalam bentuk buku teks biasa.

$\mathrm{A}_{2} \mathrm{~B}_{2}=$ Kelompok siswa yang memiliki Visual Literacy rendah yang diberi pembelajaran dengan Bhagawad Gita dalam bentuk buku teks biasa. 


\section{HASIL PENELITIAN DAN PEMBAHASAN}

Hasil penelitian dan pembahasan yang meliputi : a) Deskripsi data hasil penelitian, b) Pengujian Hipotesis, c) Pembahasan. Sebelum dilakukan uji hipotesis terlebih dahulu dilakukan pengujian persyaratan analisis terdiri dari uji normalitas dan uji homogenitas data. Deskripsi Data Hasil Penelitian Penelitian ini dilakukan untuk mengetahui perbedaan pemahaman ajaran Hindu siswa sebagai hasil perlakuan dari pembelajaran dengan menggunakan media Bhagawad Gita bergambar dan media pembelajaran Bhagawad Gita dalam bentuk buku teks biasa dengan mempertimbangkan Visual Literacy siswa. Deskripsi data pemahaman ajaran Hindu siswa yang diberikan pembelajaran menggunakan media Bhagawad Gita Bergambar disajikan dalam tabel 2.

TABEL 2

PEMAHAMAN AJARAN HINDU SISWA

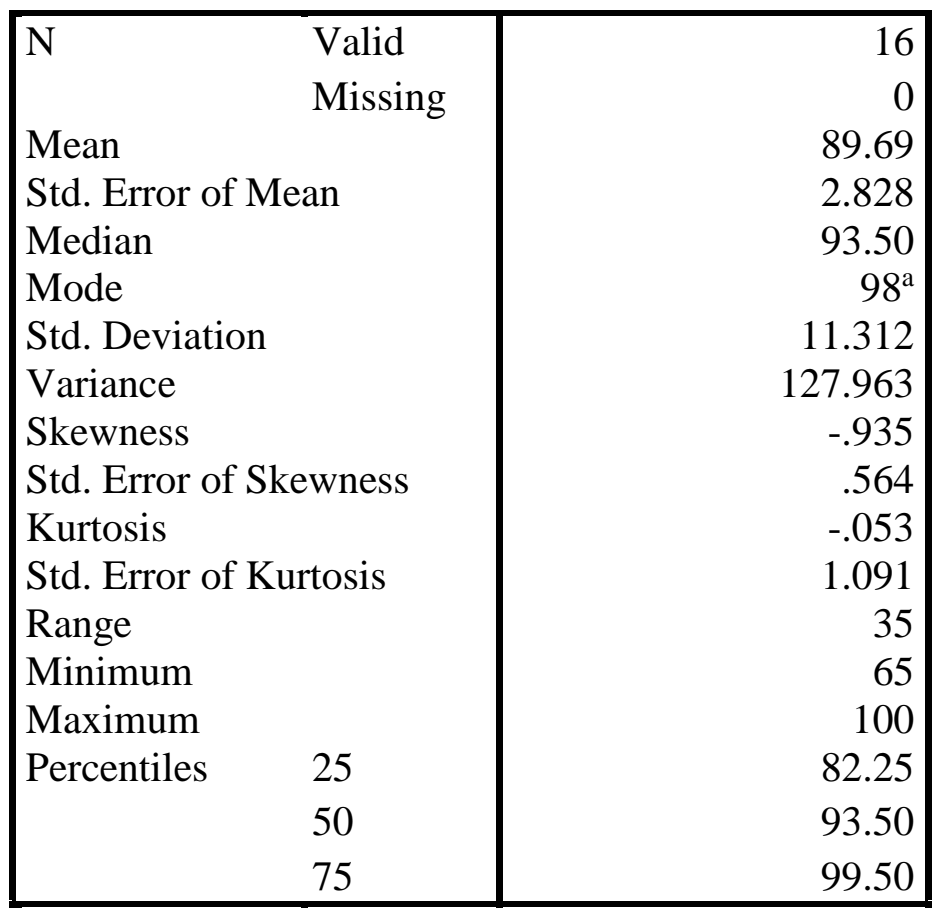

a. Multiple modes exist. The smallest value is shown

Berdasarkan data yang dikumpulkan dari 16 orang responden, diketahui data pemahaman ajaran Hindu siswa yang diberikan pembelajaran menggunakan media Bhagawad Gita bergambar tanpa membedakan Visual Literacy diperoleh 
rentang skor adalah 35, skor rata-rata 89,69, nilai median 93,50, Modus 98 varians 127,96 dan Simpangan Baku 11,31.

Jika dikaji pemahaman ajaran Hindu yang diperoleh berada dalam rentang 70-100 dengan skor rata-rata 89,69 dengan standar error 2,83. Nilai median sebesar 93,50 berarti $50 \%$ sampel memperoleh skor pemahaman ajaran Hindu 93,50 ke atas dan 50 $\%$ memperoleh skor 93,50 ke bawah. Nilai modus 98 menunjukkan bahwa skor yang paling sering tampil adalah 98.

1. Deskripsi data pemahaman ajaran Hindu siswa yang diberikan pembelajaran menggunakan media Bhagawad Gita model buku teks biasa (A2)

TABEL 3

PEMAHAMAN AJARAN HINDU SISWA

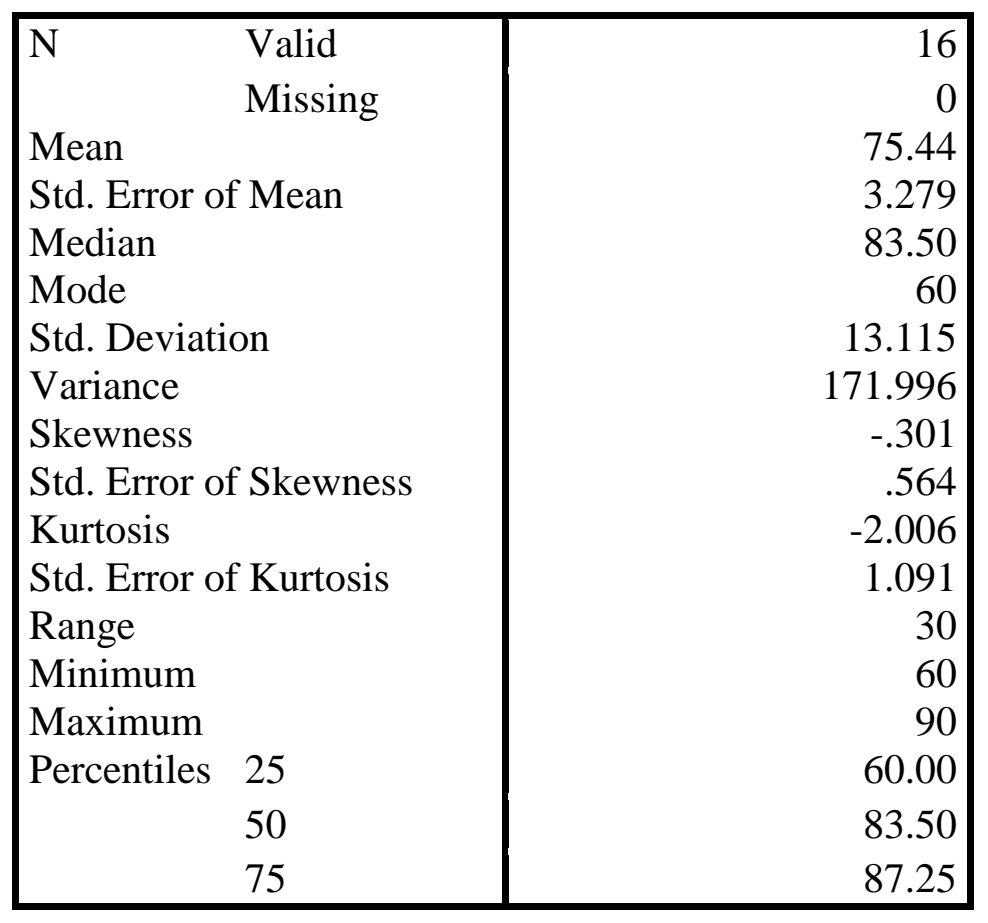

Berdasarkan pada data 16 orang responden, diketahui data pemahaman ajaran Hindu siswa yang diberikan pembelajaran dengan menggunakan media Bhagawad Gita model buku teks biasa tanpa membedakan Visual Literacy diperoleh rentang skor sama dengan 30 , skor rata-rata 75,44, nilai median 83,50 , nilai modus 60, varians 171,99, simpangan baku 13,12. 
Jika dikaji hasil pemahaman ajaran Hindu yang diperoleh berada dalam rentang 60 90 dengan skor rata-rata 75,44 dengan standar error 3,28. Nilai median sebesar 83,50 berarti $50 \%$ sampel memperoleh skor pemahaman ajaran Hindu 83,50 ke atas dan 50 $\%$ memperoleh skor 83,50 ke bawah. Nilai modus 60 menunjukkan bahwa skor yang paling sering tampil adalah 60 .

2. Deskripsi data pemahaman ajaran Hindu siswa yang memiliki Visual Literacy tinggi dan diberikan pembelajaran menggunakan media Bhagawad Gita Bergambar (A1B1)

TABEL 4

HASIL BELAJAR

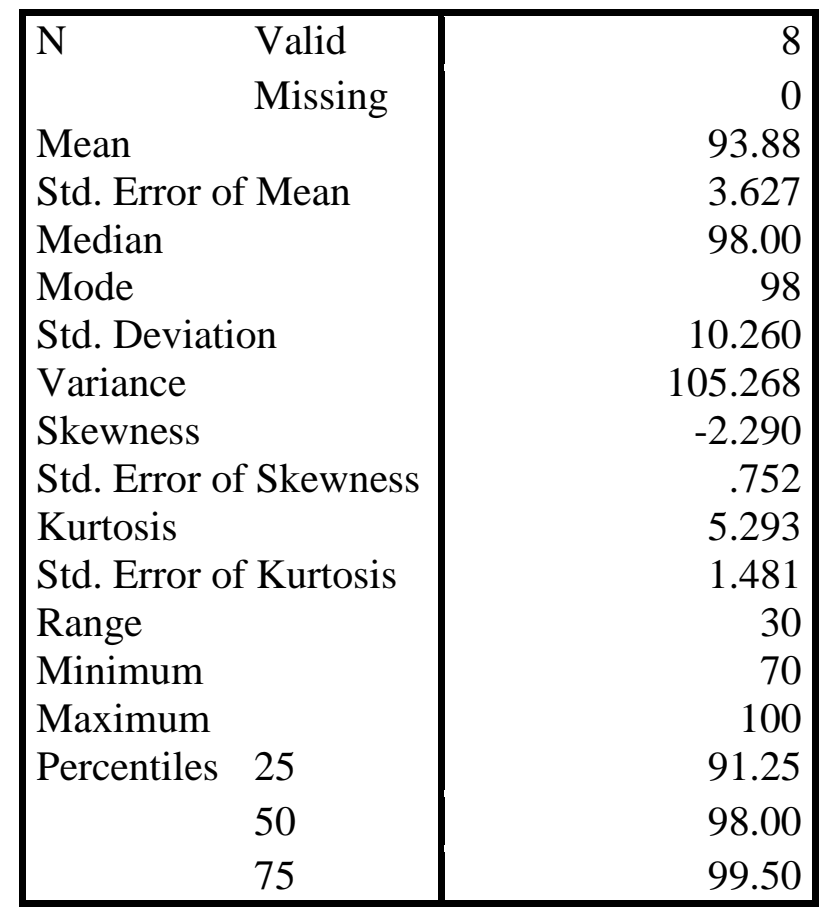

Berdasarkan pada data 8 orang responden, diketahui data pemahaman ajaran Hindu siswa yang memiliki Visual Literacy tinggi dan diberikan pembelajaran menggunakan media Bhagawad Gita bergambar diperoleh rentang skor sama dengan 30, skor rata-rata 93,88, nilai median 98,00 nilai modus 98, varians 105,27 , dan simpangan baku 10,26 
Jika dikaji hasil pemahaman ajaran Hindu yang diperoleh berada dalam rentang 70 100 dengan skor rata-rata 93,88 dengan standar error 3,63. Nilai median sebesar 98 berarti $50 \%$ sampel memperoleh skor pemahaman ajaran Hindu 98 ke atas dan $50 \%$ memperoleh skor 98 ke bawah. Nilai modus 98 menunjukkan bahwa skor yang paling sering tampil adalah 98.

3. Deskripsi data pemahaman ajaran Hindu siswa yang memiliki Visual Literacy tinggi dan diberikan pembelajaran menggunakan media Bhagawad Gita model buku teks biasa (A1B2)

TABEL 5

HASIL PEMAHAMAN AJARAN HINDU

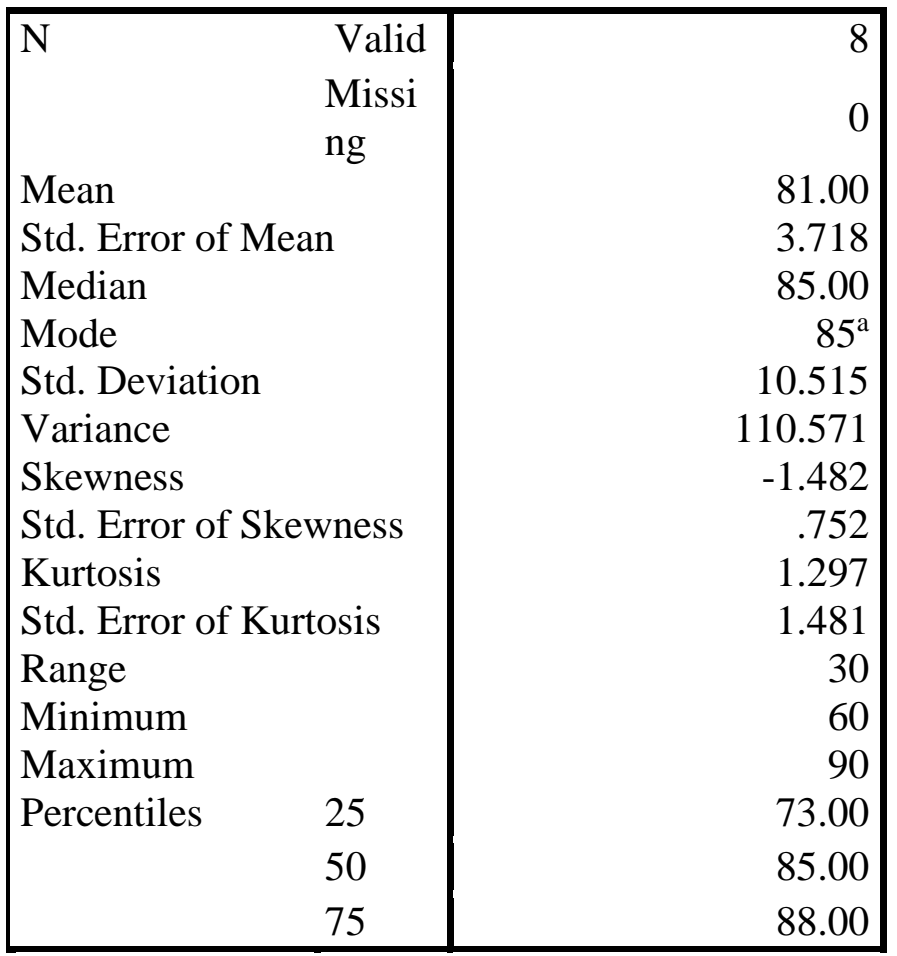

a. Multiple modes exist. The smallest value is show

Berdasarkan pada data yang dikumpulkan dari responden sebanyak 8 orang siswa, diketahui data pemahaman ajaran Hindu siswa yang memiliki Visual Literacy tinggi dan diberikan pembelajaran menggunakan media Bhagawad Gita model buku teks diperoleh rentang skor tertinggi 90 dikurangkan dengan skor 
terendah 60 sama dengan 30, skor rata-rata 81,00, nilai median 85, nilai modus 85,00 , varians 110,57 , dan simpangan baku 10,52

Jika dikaji hasil pemahaman ajaran Hindu yang diperoleh berada dalam rentang 60 90 dengan skor rata-rata 81,00 dengan standar error 3,72. Nilai median sebesar 85 berarti $50 \%$ sampel memperoleh skor pemahaman ajaran Hindu 85 ke atas dan $50 \%$ memperoleh skor 85 ke bawah. Nilai modus 85 menunjukkan bahwa pemahaman ajaran Hindu yang paling sering tampil adalah 85 .

4. Deskripsi data pemahaman ajaran Hindu siswa yang memiliki Visual Literacy rendah dan diberikan pembelajaran menggunakan media Bhagawad Gita Bergambar (A1B2)

TABEL 6

PEMAHAMAN AJARAN HINDU

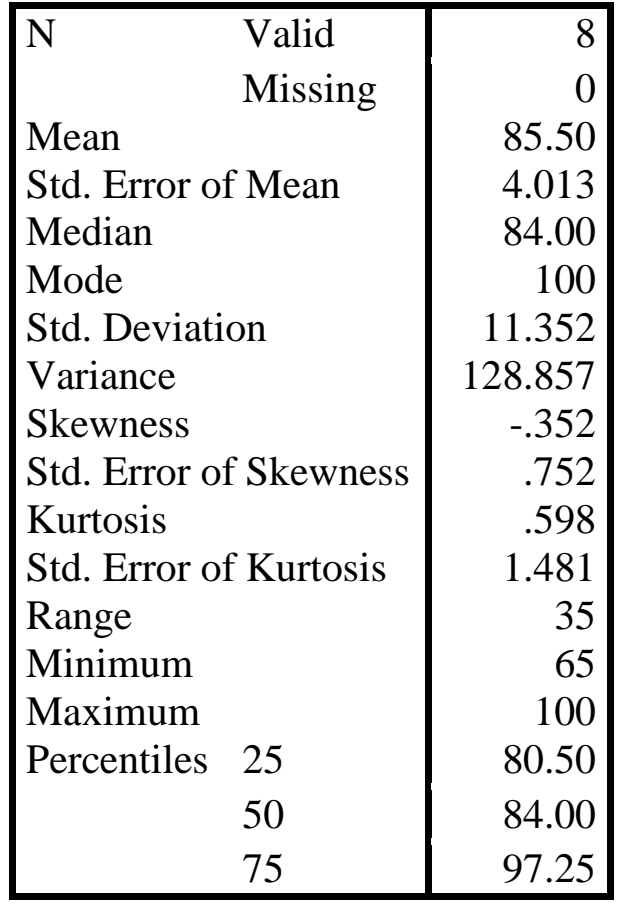

Berdasarkan pada data yang dikumpulkan dari responden sebanyak 8 orang siswa, diketahui data pemahaman ajaran Hindu siswa yang memiliki Visual Literacy rendah dan diberikan pembelajaran menggunakan media Bhagawad Gita bergambar diperoleh rentang skor tertinggi 100 dikurangkan dengan skor terendah 65 sama dengan 35 , skor rata-rata 85,50 , nilai median 84,0 , nilai modus 100 , varians 128,86, simpangan baku 11,35 
Jika dikaji hasil pemahaman ajaran Hindu yang diperoleh berada dalam rentang 65 100 dengan skor rata-rata 85,50, dengan standar error 4,01. Nilai median sebesar 84 berarti $50 \%$ sampel memperoleh skor pemahaman ajaran Hindu 84 ke atas dan $50 \%$ memperoleh skor 84 ke bawah. Nilai modus 100 menunjukkan bahwa skor yang paling sering tampil adalah 100 .

5. Deskripsi data pemahaman ajaran Hindu siswa yang memiliki Visual Literacy rendah dan diberikan pembelajaran menggunakan media Bhagawad Gita model Buku teks biasa (A2B2)

TABEL 7

\begin{tabular}{|c|c|c|}
\hline \multicolumn{3}{|c|}{ AJAKAN HIND } \\
\hline $\mathrm{N}$ & $\begin{array}{l}\text { Valid } \\
\text { Missino }\end{array}$ & $\begin{array}{l}8 \\
0\end{array}$ \\
\hline \multicolumn{2}{|l|}{ Mean } & 69.88 \\
\hline \multicolumn{2}{|c|}{ Std. Error of Mean } & 4.838 \\
\hline \multicolumn{2}{|c|}{ Median } & 60.00 \\
\hline \multicolumn{2}{|c|}{ Mode } & 60 \\
\hline \multicolumn{2}{|c|}{ Std. Deviation } & 13.685 \\
\hline \multicolumn{2}{|c|}{ Variance } & 187.268 \\
\hline \multicolumn{2}{|c|}{ Skewness } & .676 \\
\hline \multicolumn{2}{|c|}{ Std. Error of Skewness } & .752 \\
\hline \multicolumn{2}{|c|}{ Kurtosis } & -2.104 \\
\hline \multicolumn{2}{|c|}{ Std. Error of Kurtosis } & 1.481 \\
\hline \multicolumn{2}{|c|}{ Range } & 29 \\
\hline \multicolumn{2}{|l|}{ Minimum } & 60 \\
\hline \multicolumn{2}{|l|}{ Maximum } & 89 \\
\hline \multirow[t]{3}{*}{ Percentiles } & 25 & 60.00 \\
\hline & 50 & 60.00 \\
\hline & 75 & 85.00 \\
\hline
\end{tabular}

Berdasarkan pada data yang dikumpulkan dari responden sebanyak 8 orang siswa, diketahui data pemahaman ajaran Hindu siswa yang memiliki Visual Literacy rendah dan diberikan pembelajaran menggunakan media Bhagawad Gita model teks biasa diperoleh rentang skor tertinggi 89 dikurangkan dengan skor terendah 60 sama dengan 29, skor rata-rata 69,88, nilai median 60,00, nilai modus 60,00, varians 187,27, simpangan baku 13,69. 
Jika dikaji hasil pemahaman ajaran Hindu yang diperoleh berada dalam rentang 60 89 dengan skor rata-rata 69,88 dengan standar error 4,84. Nilai median sebesar 60 berarti $50 \%$ sampel memperoleh skor pemahaman ajaran Hindu 60 ke atas dan $50 \%$ memperoleh skor 60 ke bawah. Nilai modus 60 menunjukkan bahwa skor yang paling sering tampil adalah 60 .

6. Deskripsi data perbandingan pemahaman ajaran Hindu siswa yang diberikan pembelajaran menggunakan media Bhagawad Gita model bergambar dan model buku teks biasa

TABEL 8

PERBANDINGAN HASIL PEMAHAMAN AJARAN HINDU SISWA YANG DIBERIKAN PEMBELAJARAN MENGGUNAKAN MEDIA BHAGAWAD GITA MODEL BERGAMBAR DAN MODEL BUKU TEKS BIASA

\begin{tabular}{|c|c|c|c|c|c|}
\hline & MEDIA PEMBI & LAJARAN & & Statistic & $\begin{array}{l}\text { Std. } \\
\text { Error }\end{array}$ \\
\hline HASIL & BG & Mean & & 89.69 & 2.828 \\
\hline PEMAHAM & BERGAMBAR & $95 \%$ Confidence & Lower & 83.66 & \\
\hline & & Interval for Mean & Bound & & \\
\hline $\begin{array}{l}\text { AJARAN } \\
\text { HINDU }\end{array}$ & & & $\begin{array}{l}\text { Upper } \\
\text { Bound }\end{array}$ & 95.72 & \\
\hline & & $5 \%$ Trimmed Mea & & 90.49 & \\
\hline & & Median & & 93.50 & \\
\hline & & Variance & & 127.963 & \\
\hline & & Std. Deviation & & 11.312 & \\
\hline & & Minimum & & 65 & \\
\hline & & Maximum & & 100 & \\
\hline & & Range & & 35 & \\
\hline & & Interquartile Rang & & 17 & \\
\hline & & Skewness & & -.935 & .564 \\
\hline & & Kurtosis & & -.053 & 1.091 \\
\hline & BG TEKS & Mean & & 75.44 & 3.279 \\
\hline & BIASA & $\begin{array}{l}95 \% \text { Confidence } \\
\text { Interval for Mean }\end{array}$ & $\begin{array}{l}\text { Lower } \\
\text { Bound } \\
\text { Upper } \\
\text { Bound }\end{array}$ & 68.45 & \\
\hline
\end{tabular}




\begin{tabular}{|l|r|r|}
\hline $5 \%$ Trimmed Mean & 75.49 & \\
\hline Median & 83.50 & \\
\hline Variance & 171.996 & \\
\hline Std. Deviation & 13.115 & \\
\hline Minimum & 60 & \\
\hline Maximum & 90 & \\
\hline Range & 30 & \\
\hline Interquartile Range & 27 & \\
\hline Skewness & -.301 & .564 \\
\hline Kurtosis & -2.006 & 1.091 \\
\hline
\end{tabular}

Rata-rata hasil pemahaman ajaran Hindu siswa yang diberikan pembelajaran dengan menggunakan media Bhagawad Gita bergambar adalah 89,69 dengan tingkat kepercayaan $95 \%$ rata-rata tersebut dapat mengestimasi rata-rata populasi pada kisaran antara 83,66 sampai 95,72. Sedangkan rata-rata untuk siswa yang diberikan pembelajaran dengan menggunakan media pembelajaran Bhagawad Gita model buku teks biasa sebesar 75,44, rata-rata tersebut dapat mengestimasi rata-rata populasi pada kisaran 68,45 sampai 82,43.

7. Deskripsi data perbandingan pemahaman ajaran Hindu siswa yang memiliki tingkat Visual Literacy tinggi dan rendah. Rata-rata hasil pemahaman ajaran Hindu siswa yang memiliki Visual Literacy tinggi adalah 87,44 dengan tingkat kepercayaan $95 \%$ rata-rata tersebut dapat mengestimasi rata-rata populasi pada kisaran antara 81,02 sampai 93,85. Sedangkan rata-rata untuk siswa yang yang memiliki Visual Literacy rendah sebesar 77,69, rata-rata tersebut dapat mengestimasi rata-rata populasi pada kisaran 69,92 sampai 85,46. (ditunjukan dalam tabel 9 
TABEL 9

PERBANDINGAN HASIL PEMAHAMAN AJARAN HINDU YANG MEMILIKI

VISUAL LITERACY TINGGI DAN RENDAH

\begin{tabular}{|c|c|c|c|c|c|}
\hline & \multicolumn{3}{|c|}{ VISUAL LITERACY } & Statistic & Std. Error \\
\hline \multirow{27}{*}{$\begin{array}{l}\text { HASIL } \\
\text { PEMAHAM } \\
\text { AN AJARAN } \\
\text { HINDU }\end{array}$} & \multirow{14}{*}{ TINGGI } & \multicolumn{2}{|l|}{ Mean } & 87.44 & 3.010 \\
\hline & & \multirow{3}{*}{$\begin{array}{l}95 \% \text { Confidence } \\
\text { Interval for Mean }\end{array}$} & Lower & 810 & \\
\hline & & & Bound & 01.02 & \\
\hline & & & $\begin{array}{l}\text { Upper } \\
\text { Bound }\end{array}$ & 93.85 & \\
\hline & & \multicolumn{2}{|l|}{ 5\% Trimmed Mean } & 88.26 & \\
\hline & & \multicolumn{2}{|l|}{ Median } & 88.50 & \\
\hline & & \multicolumn{2}{|l|}{ Variance } & 144.929 & \\
\hline & & \multicolumn{2}{|l|}{ Std. Deviation } & 12.039 & \\
\hline & & \multicolumn{2}{|l|}{ Minimum } & 60 & \\
\hline & & \multicolumn{2}{|l|}{ Maximum } & 100 & \\
\hline & & \multicolumn{2}{|l|}{ Range } & 40 & \\
\hline & & \multicolumn{2}{|l|}{ Interquartile Range } & 15 & \\
\hline & & \multicolumn{2}{|l|}{ Skewness } & -.993 & .564 \\
\hline & & \multicolumn{2}{|l|}{ Kurtosis } & .334 & 1.091 \\
\hline & \multirow[t]{13}{*}{ RENDAH } & \multicolumn{2}{|l|}{ Mean } & 77.69 & 3.645 \\
\hline & & \multirow[t]{2}{*}{$\begin{array}{l}\text { 95\% Confidence } \\
\text { Interval for Mean }\end{array}$} & $\begin{array}{l}\text { Lower } \\
\text { Bound }\end{array}$ & 69.92 & \\
\hline & & & $\begin{array}{l}\text { Upper } \\
\text { Bound }\end{array}$ & 85.46 & \\
\hline & & \multicolumn{2}{|l|}{ 5\% Trimmed Mean } & 77.43 & \\
\hline & & \multicolumn{2}{|l|}{ Median } & 82.50 & \\
\hline & & \multicolumn{2}{|l|}{ Variance } & 212.629 & \\
\hline & & \multicolumn{2}{|l|}{ Std. Deviation } & 14.582 & \\
\hline & & \multicolumn{2}{|l|}{ Minimum } & 60 & \\
\hline & & \multicolumn{2}{|l|}{ Maximum } & 100 & \\
\hline & & \multicolumn{2}{|l|}{ Range } & 40 & \\
\hline & & \multicolumn{2}{|l|}{ Interquartile Range } & 28 & \\
\hline & & \multicolumn{2}{|l|}{ Skewness } & -.078 & .564 \\
\hline & & \multicolumn{2}{|l|}{ Kurtosis } & -1.387 & 1.091 \\
\hline
\end{tabular}

Pengujian Hipotesis

Setelah dilakukan uji persyaratan analisis yaitu dengan uji normalitas data, ternyata ditemukan bahwa data kelompok berdistribusi normal dan homogen oleh karena itu untuk pengujian hipotesis dapat dilanjutkan dengan Uji Anova (analisis of variance dalam hal ini dengan menggunakan SPSS Ver 23. 
TABEL 10

Descriptive Statistics

Dependent Variable: PEMAHAMAN AJARAN HINDU

\begin{tabular}{|c|c|c|c|c|}
\hline $\begin{array}{c}\text { MEDIA } \\
\text { PEMBELAJARAN }\end{array}$ & $\begin{array}{c}\text { VISUAL } \\
\text { LITERACY }\end{array}$ & Mean & $\begin{array}{c}\text { Std. } \\
\text { Deviation }\end{array}$ & $\mathrm{N}$ \\
\hline \multirow[t]{3}{*}{ BG BERGAMBAR } & TINGGI & 93.88 & 10.260 & 8 \\
\hline & RENDAH & 85.50 & 11.352 & 8 \\
\hline & Total & 89.69 & 11.312 & 16 \\
\hline \multirow[t]{3}{*}{ BG TEKS BIASA } & TINGGI & 81.00 & 10.515 & 8 \\
\hline & RENDAH & 69.88 & 13.685 & 8 \\
\hline & Total & 75.44 & 13.115 & 16 \\
\hline \multirow[t]{3}{*}{ Total } & TINGGI & 87.44 & 12.039 & 16 \\
\hline & RENDAH & 77.69 & 14.582 & 16 \\
\hline & Total & 82.56 & 14.055 & 32 \\
\hline
\end{tabular}

Dari hasil analisis secara deskriptif dalam tabel di atas menunjukkan bahwa kemampuan pemahaman ajaran Hindu siswa yang memiliki Visual Literacy tinggi dan diberikan pembelajaran menggunakan media Bhagawad Gita bergambar rata-rata sebesar 93,88 sedangkan yang diberikan pembelajaran menggunakan media Bhagawad Gita model teks biasa rata-rata sebesar 81,00. Untuk siswa yang memiliki Visual Literacy rendah dan diberikan pembelajaran menggunakan media Bhagawad Gita bergambar memperoleh rata-rata sebesar 85,50 sedangkan yang diberikan media Bhagawad Gita model teks biasa memperoleh rata-rata sebesar 69,88.

Uji Hipotesis Pertama

Hipotesis : Secara Keseluruhan ada perbedaan Pemahaman ajaran Hindu Siswa kelas IX yang diberikan media pembelajaran Bhagawad Gita Bergambar dengan yang melalui pembelajaran dengan media Bhagawad Gita Model teks biasa

Secara statistik, hipotesis ini dirumuskan sebagai berikut :

$\mathrm{H} 0: \mu \mathrm{A} 1=\mu \mathrm{A} 2$

На $: \mu \mathrm{A} 1 \neq \mu \mathrm{A} 2$

Keterangan :

$\mathrm{A} 1=$ Rata-rata skor pemahaman ajaran Hindu siswa yang diberikan pembelajaran dengan media Bhagawad Gita bergambar

$\mu \mathrm{A} 2$ = Rata-rata skor pemahaman ajaran Hindu siswa yang diberikan pembelajaran dengan media Bhagawad Gita model teks biasa 
Kesimpulan :

Jika F hitung $\leq \mathrm{F}$ tabel pada $\alpha=0,05$, Ho diterima

Jika F hitung $>$ F tabel pada $\alpha=0,05$, Ho ditolak

TABEL 11

Tests of Between-Subjects Effects

Dependent Variable: PEMAHAMAN AJARAN HINDU

\begin{tabular}{|l|r|r|r|r|r|}
\hline Source & $\begin{array}{c}\text { Type III } \\
\text { Sum of } \\
\text { Squares }\end{array}$ & df & \multicolumn{1}{c|}{$\begin{array}{c}\text { Mean } \\
\text { Square }\end{array}$} & \multicolumn{1}{c|}{ F } & \multicolumn{1}{c|}{ Sig. } \\
\hline Corrected & $2400.125^{\mathrm{a}}$ & 3 & 800.042 & 6.016 & .003 \\
Model & 218130.125 & 1 & 218130.125 & 1640.186 & .000 \\
Intercept & 1624.500 & 1 & 1624.500 & 12.215 & .002 \\
A & 760.500 & 1 & 760.500 & 5.718 & .024 \\
B & 15.125 & 1 & 15.125 & .114 & .738 \\
A B & 3723.750 & 28 & 132.991 & & \\
Error & 224254.000 & 32 & & & \\
Total & 6123.875 & 31 & & & \\
Corrected & & & & \\
Total & & & & & \\
\hline
\end{tabular}

a. R Squared $=.392$ (Adjusted R Squared $=.327$ )

Pengaruh Utama (Main Effect)

Dari tabel di atas :

a. $\mathrm{Fo}(\mathrm{A})=12,215>\mathrm{F}$ tabel $=4,15$ pada $\alpha 0,05$, Ho ditolak artinya terdapat perbedaan pemahaman ajaran Hindu siswa yang diberikan pembelajaran media Bhagawad Gita Bergambar dengan yang diberikan media Bhagawad Gita model teks biasa.

b. $\quad F o(B)=5,718>\mathrm{F}$ tabel $=4,15$ pada $\alpha 0,05$, Ho ditolak artinya terdapat perbedaan pemahaman ajaran Hindu siswa yang memiliki tingkat Visual Literacy tinggi dan yang rendah.

Pengaruh Interaksi (Interaction Effect)

Fo $(\mathrm{AB})=0,114 \leq \mathrm{F}$ tabel $=4,15$ pada $\alpha 0,05$ dengan demikian tidak terdapat pengaruh interaksi antara media pembelajaran dengan Visual Literacy dan digambarkan dalam grafik pada gambar 4 
Grafik Pngaruh Interaksi antara Media Pembelajaran dengan Visual Literacy

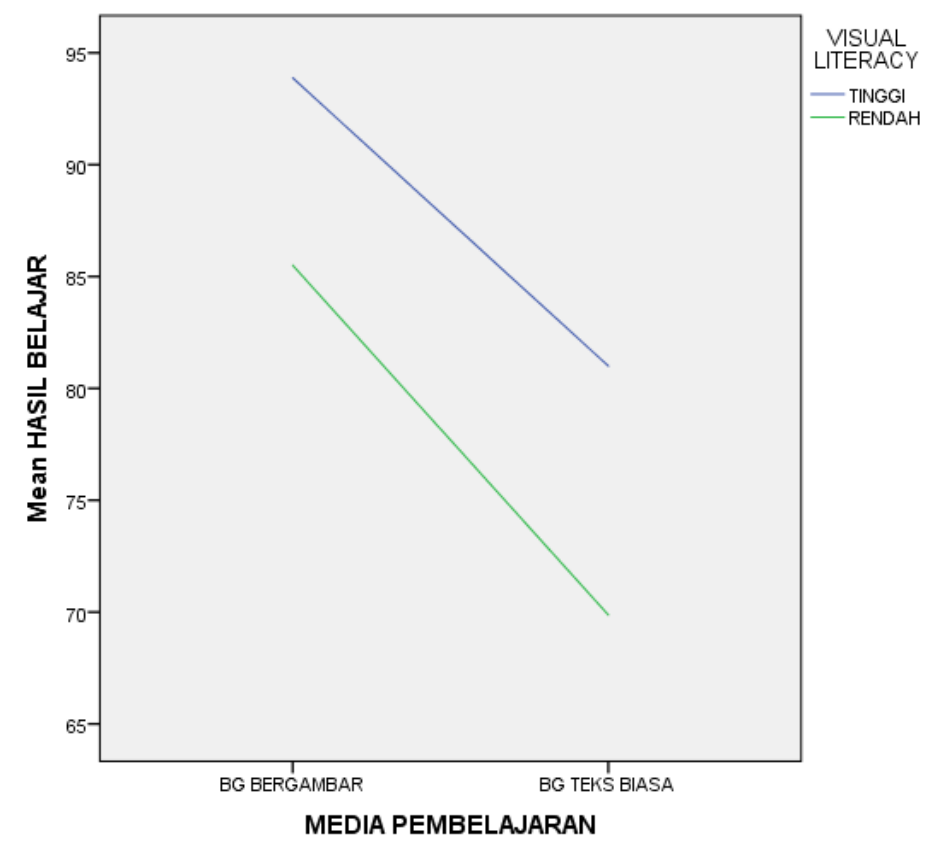

GAMBAR 4

Uji Hipotesis Kedua

Pemahaman ajaran Hindu siswa kelas IX yang memiliki Visual Literacy tinggi, dan diberikan pembelajaran dengan media Bhagawad Gita bergambar, lebih tinggi dari pada yang melalui pembelajaran dengan media Bhagawad Gita model teks biasa.

Secara statistik, hipotesis ini dirumuskan sebagai berikut :

$\mathrm{H}_{\mathrm{o}} \quad: \quad \mu_{\mathrm{A}_{1} \mathrm{~B}_{1}} \leq \mu \mathrm{A}_{2} \mathrm{~B}_{1}$

$\mathrm{H}_{\mathrm{a}} \quad: \quad \mu \mathrm{A}_{1} \mathrm{~B}_{1}>\mu \mathrm{A}_{2} \mathrm{~B}_{1}$

Keterangan :

$\mu_{\mathrm{A}_{1} \mathrm{~B}_{1}}=$ Rata-rata skor hasil pemahaman ajaran Hindu siswa memiliki Visual Literacy tinggi dan yang diberikan pembelajaran dengan media Bhagawad Gita bergambar

$\mu_{\mathrm{A}_{2} \mathrm{~B}_{1}}=$ Rata-rata skor pemahaman ajaran Hindu siswa memiliki Visual Literacy tinggi dan yang diberikan pembelajaran dengan media Bhagawad Gita model teks biasa.

Dari baris corrected model pada tabel Test of Between Subject-effect, di bawah diperoleh harga $\mathrm{F}=6,016$ dan $\mathrm{p}$ value $=0,003<0,05$, berarti Ho ditolak. Dengan demikian terdapat perbedaan rata-rata yang signifikan antara 4 kelompok. 
TABEL 12

Tests of Between-Subjects Effects

Dependent Variable: PEMAHAMAN AJARAN HINDU

\begin{tabular}{|l|r|r|r|r|r|}
\hline Source & $\begin{array}{c}\text { Type III Sum } \\
\text { of Squares }\end{array}$ & df & \multicolumn{1}{c|}{$\begin{array}{c}\text { Mean } \\
\text { Square }\end{array}$} & \multicolumn{1}{c|}{ F } & \multicolumn{1}{c|}{ Sig. } \\
\hline Corrected & $2400.125^{\mathrm{a}}$ & 3 & 800.042 & 6.016 & .003 \\
Model & 218130.125 & 1 & 218130.125 & 1640.186 & .000 \\
Intercept & 1624.500 & 1 & 1624.500 & 12.215 & .002 \\
$\mathrm{~A}$ & 760.500 & 1 & 760.500 & 5.718 & .024 \\
$\mathrm{~B}$ & 15.125 & 1 & 15.125 & .114 & .738 \\
A $*$ B & 3723.750 & 28 & 132.991 & & \\
Error & 224254.000 & 32 & & & \\
Total & 6123.875 & 31 & & & \\
Corrected & & & & \\
Total & & & & \\
\hline
\end{tabular}

a. $\mathrm{R}$ Squared $=.392($ Adjusted $\mathrm{R}$ Squared $=.327)$

Pengujian Simple effect untuk B1

Berdasarkan koefisien kontras yang ditunjukan dalam tabel dibawah, Perbedaan antar A pada B1 (A1B1 dan A2B1)

t0 $(\mathrm{A} 1 \mathrm{~B} 1-\mathrm{A} 2 \mathrm{~B} 1)=2,233, \mathrm{p}$ value $=0,034 / 2=0,017<0,05$ atau $\mathrm{H} 0$ ditolak

Dengan demikian hasil pemahaman ajaran Hindu siswa yang memiliki Visual

Literacy tinggi dan diberikan media pembelajaran Bhagawad Gita bergambar lebih tinggi dari pada yang diberikan media pembelajaran Bhagawad Gita model teks biasa.

TABEL. 13

Contrast Tests

\begin{tabular}{|l|l|l|r|r|r|r|r|}
\hline & & $\begin{array}{l}\text { Contras } \\
\mathrm{t}\end{array}$ & $\begin{array}{r}\text { Value of } \\
\text { Contrast }\end{array}$ & $\begin{array}{c}\text { Std. } \\
\text { Error }\end{array}$ & \multicolumn{1}{c|}{$\mathrm{t}$} & $\mathrm{c}$ & $\begin{array}{c}\text { Sig. (2- } \\
\text { tailed) }\end{array}$ \\
\hline PEMA- & Assume & 1 & 12.88 & 5.766 & 2.233 & 28 & .034 \\
HAMAN & equal & 2 & 8.38 & 5.766 & 1.452 & 28 & .157 \\
AJARAN variance & 3 & 24.00 & 5.766 & 4.162 & 28 & .000 \\
HINDU & $\mathrm{s}$ & 4 & -4.50 & 5.766 & -.780 & 28 & .442 \\
& & 5 & 11.13 & 5.766 & 1.929 & 28 & .064 \\
& & 6 & 15.63 & 5.766 & 2.710 & 28 & .011 \\
\cline { 2 - 7 } & Does not & 1 & 12.88 & 5.194 & 2.479 & 13.992 & .027 \\
& assume & 2 & 8.38 & 5.410 & 1.548 & 13.859 & .144 \\
& equal & 3 & 24.00 & 6.047 & 3.969 & 12.980 & .002 \\
& variance & 4 & -4.50 & 5.471 & -.823 & 13.919 & .425 \\
& s & 5 & 11.13 & 6.102 & 1.823 & 13.129 & .091 \\
& 6 & 15.63 & 6.286 & 2.486 & 13.538 & .027 \\
\hline
\end{tabular}




\section{Uji Hipotesis Ketiga}

Pemahaman ajaran Hindu siswa kelas IX yang memiliki Visual Literacy rendah, dan diberikan pembelajaran dengan media Bhagawad Gita bergambar, lebih rendah dari pada yang melalui pembelajaran dengan media Bhagawad Gita model teks biasa.

Secara statistik, hipotesis ini dirumuskan sebagai berikut :

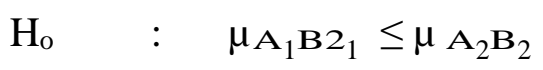

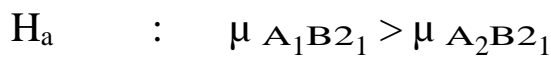

Keterangan :

$\mu_{\mathrm{A}_{1} \mathbf{B}_{2}}=$ Rata-rata skor pemahaman ajaran Hindu siswa memiliki Visual Literacy rendah dan yang diberikan pembelajaran dengan media Bhagawad Gita bergambar

$\mu_{\mathrm{A}_{2} \mathbf{B}_{2}}=$ Rata-rata skor pemahaman ajaran Hindu siswa memiliki Visual Literacy rendah dan yang diberikan pembelajaran dengan media Bhagawad Gita model teks biasa.

Pengujian Simple effect untuk B2

Berdasarkan koefisien kontras yang ditunjukkan dalam tabel dibawah, Perbedaan antar A pada B2 (A1B2 dan A2B2)

t0 $(\mathrm{A} 1 \mathrm{~B} 2-\mathrm{A} 2 \mathrm{~B} 2)=1,452, \mathrm{p}$ value $=0,157 / 2=0,0785>0,05$ atau $\mathrm{H} 0$ diterima . Dengan demikian rata-rata pemahaman ajaran Hindu siswa yang memiliki Visual Literacy rendah dan diberikan media pembelajaran Bhagawad Gita bergambar lebih tinggi dari pada yang diberikan media pembelajaran Bhagawad Gita model teks biasa.

Pengujian hipotesis pertama, menunjukkan berhasil menolak H0 yang menyatakan terdapat perbedaan pemahaman ajaran Hindu Siswa kelas IX yang diberikan media pembelajaran Bhagawad Gita bergambar dan yang melalui pembelajaran dengan media Bhagawad Gita model teks biasa. Media pembelajaran Bhagawad Gita bergambar yang digunakan secara signifikan memberikan pengaruh bila dibandingkan dengan media yang berupa teks biasa. Ternyata hasil pemahaman ajaran Hindu Siswa yang diberikan pembelajaran dengan media Bhagawad Gita bergambar secara konsisten memberikan hasil yang lebih tinggi terhadap skor rata-rata siswa dari pada yang menggunakan media Bhagawad Gita dengan model teks biasa. Bhagawad Gita yang disertai gambar tersebut lebih kongkrit dan menyenangkan sehingga siswa cenderung lebih mudah untuk memaknainya melalui diskusi maupun tanya jawab 
dalam pembelajaran di kelas baik sesama siswa maupun dengan guru. Ini sesuai dengan fungsi media dapat mengkongkritkan yang abstrak sehingga memudahkan belajar bagi siswa. Proses komunikasi pembelajaran terjadi secara efektif karena memperhatikan beberapa hal agar fungsi media mencapai sasaran yaitu sebagai sarana komunikasi antara komunikator dan penerima, dimana penerima dapat memahami isi pesan yang terdapat dalam media, ini sesuai dengan model komunikasi yang di ungkapkan oleh Wilbur Schramm. (Prawiradilaga, 2004, p. 8).

Hipotesis Kedua, Hasil pengujian hipotesis kedua berhasil menolak hipotesis nol yang menyatakan bahwa terdapat perbedaan rata-rata pemahaman siswa yang memiliki Visual Literacy tinggi dan diberikan pembelajaran menggunakan media Bhagawad Gita bergambar dengan yang menggunakan media Bhagawad Gita dalam teks biasa. Dari hasil pengujian hipotesis ditunjukan bahwa rata-rata skor pemahaman siswa dalam pemahaman ajaran Hindu dalam aspek yadnya oleh siswa yang memiliki Visual Literacy tinggi dan diberikan pembelajaran menggunakan media Bhagawad Gita bergambar lebih tinggi dari pada yang diberikan pembelajaran menggunakan media Bhagawad Gita model teks biasa. Tingkat Visual Literacy yang tinggi pada diri siswa dapat membawa perbedaan yang signifikan sehingga memberikan kemampuan setiap individu untuk lebih mampu menginterpretasi lambang-lambang visual dan memberikan kemampuan individu untuk lebih mudah mengerti gambar-gambar visual menjadi sangat penting. Selaras dengan apa yang diungkapkan oleh Robert Heinich bahwa Visual literacy adalah kemampuan peserta didik untuk menganalisis sebuah pesan visual dalam pembelajaran, dalam bukunya yang berjudul Instructional Media.(Heinich, Robert, Michel Molenda, 1982, p. 62)

Pada hipotesis ketiga bahwa hipotesis nol diterima dengan demikian skor rata-rata pemahaman siswa dengan Visual Literacy rendah yang diberikan pembelajaran dengan menggunakan media Bhagawad Gita model buku teks biasa ternyata lebih rendah dari pada yang menggunakan media Bhagawad Gita model bergambar. Ini menunjukkan ketika siswa memiliki tingkat Visual Literacy rendah tidak terlalu berpengaruh sehingga diberikan media visual dengan Bhagawad Gita bergambar mereka lebih mudah dalam belajar karena lebih kongkrit. Meskipun demikian akan lebih baik lagi jika Visual Literacynya dilatih untuk bisa lebih tinggi lagi sehingga dalam mengiterprestasi gambar-gambar maupun lambang visual mereka lebih mudah 
dalam memahami hal -hal yang abstrak, ini selaras dengan pendapat Robert Heinich di atas.

\section{KESIMPULAN}

Berdasarkan hasil pengujian hipotesis, penelitian ini membuktikan bahwa :

1. Terdapat perbedaan yang signifikan yaitu Pemahaman ajaran Hindu siswa yang mengikuti pembelajaran dengan menggunakan Media Bhagawad Gita Bergambar lebih tinggi dari pada yang mengikuti pembelajaran menggunakan Media Bhagawad Gita model uku teks biasa.

2. Terdapat perbedaan yang signifikan yaitu Pemahaman ajaran Hindu siswa yang diberikan pembelajaran menggunakan media Bhagawad Gita bergambar lebih tinggi dari pada yang mengikuti pembelajaran dengan media Bhagawad Gita model buku teks biasa bagi siswa yang memiliki Visual Literacy tinggi

3. Tidak Terdapat perbedaan yang signifikan yaitu pemahaman ajaran Hindu yang diberikan pembelajaran menggunakan media Bhagawad Gita bergambar tetap lebih tinggi dari pada yang mengikuti pembelajaran dengan media Bhagawad Gita model buku teks biasa bagi siswa yang memiliki Visual Literacy rendah. Pemahaman ajaran Hindu, pada siswa yang memiliki Visual Literacy rendah yang mengikuti pembelajaran dengan media Bhagawad Gita model buku teks biasa lebih rendah dari pada siswa yang mengikuti pembelajaran dengan menggunakan media Bhagawad Gita bergambar. Ini menunjukkan ketika siswa memiliki tingkat Visual Literacy rendah tidak terlalu berpengaruh sehingga diberikan media visual dengan Bhagawad Gita bergambar mereka lebih mudah dalam belajar karena lebih kongkrit. 


\section{DAFTAR PUSTAKA}

Asyhar, R. H. (2011). Kreatif Mengembangkan Media Pembelajaran. Jakarta: Gaung Persada Press.

Gun, G. (2011). Bhagawad Gita Terjemahan Bergambar. Denpasar: Penerbit ESBE.

Heinich, Robert, Michel Molenda, J. D. R. (1982). Instructional Media and The New Technologies of Instruction. New York: John Wiley \& Sons Inc.

Munir. (2008). Kurikulum berbasis teknologi informasi dan komunikasi. Bandung: Alfabeta.

Prabhupada, A.C Swami Bhaktivedanta, S. S. (2006). Bhagawad Gita Menurut Aslinya. Jakarta: Hanuman Sakti dibawah lisensi The Bhaktivedanta Book Trust.

Prawiradilaga, D. S. \& E. S. (2004). Mozaik Teknologi Pendidikan. Jakarta: Kencana Prenada Media Group \& UNJ.

Riduan. (2011). Dasar-dasar Statistika. Bandung: Penerbit Alfa Beta.

Sugiyono. (2008). Metodologi Penelitian Pendidikan, Pendekatan Kuantitaif, Kualitatif dan R\&D. Bandung: Penerbit Alfa beta. 